\title{
PERAN PENDIDIKAN FORMAL DAN KONSEP DIRI TERHADAP POTENSI KEWIRAUSAHAAN PADA MAHASISWA
}

\author{
Zulia Khairani $^{1}$, Faizah Kamilah $^{2}$, Efrita Soviyanti ${ }^{3}$ \\ ${ }^{1,2,3}$ Fakultas Ekonomi Universitas Lancang Kuning \\ Jln. D.I. Panjaitan KM 8 Rumbai Pekanbaru \\ E-mail : zuliakhairani@unilak.ac.id
}

\begin{abstract}
In the midst of the high number of employee deductions made by many companies at this time, it is very necessary for the younger generation to have the ability to entrepreneurship so as to be able to run their business independently. This study aims to identify the role of formal education, self-concept, and its effect on entrepreneurship potential in students. The population in this study is a student of Faculty of Economics, University of Lancang Kuning. Methods of data retrieval using an online questionnaire. Data processing uses quantitative analysis through descriptive analysis, multiple regression analysis, and hypothesis testing with t-test and F-test. Qualitative analysis is done by interpretation of the data obtained in the research and the results of data processing that has been implemented by giving information and explanation. The results of descriptive data indicate that formal education, self-concept, and entrepreneurship potential of students of faculty of economics management study program in good criterion. Formal education and self-concept positively and significantly affect the entrepreneurial potential of students. This means that improvements in the quality of formal education and self-concept will increase the potential of entrepreneurship in students.
\end{abstract}

Keywords: Formal Education, Self Concept, Potential of Student Entrepreneurship

\section{PENDAHULUAN}

Di era digital saat ini dimana peran manusia sebagai tenaga kerja telah banyak digantikan oleh sistem informasi dan robot. Selain itu tingginya tingkat persaingan antar perusahaan dalam satu industri mengharuskan perusahaan memangkas berbagai biaya untuk efisiensi sehingga dapat menawarkan harga yang bersaing kepada konsumennya. Saat ini banyak perusahaan yang mengurangi jumlah karyawan dengan alasan efisiensi. Hal ini menandakan bahwa persaingan bagi calon pencari kerja akan semakin ketat dalam mendapatkan pekerjaan yang layak. Solusi yang paling tepat dalam mengatasi ini adalah menyiapkan generasi muda untuk memiliki kemampuan berwirausaha agar nantinya dapat mengelola usahanya secara mandiri.
Kewirausahaan diakui secara global sebagai strategi pengembangan ekonomi yang kritis untuk pekerjaan dan penciptaan kekayaan (Nyadu-Addo \& Mensah, 2017). Menurut (Simanjuntak, Awwaliyah, \& Artanto, 2016) Kewirausahaan memainkan peran vital dalam pengembangan ekonomi negara manapun dan bisa dihubungkan untuk pertumbuhan ekonomi negara manapun. Sebagai sebuah negara berkembang, Indonesia diharapkan akan memiliki jumlah pengusaha yang besar, karena semakin besar jumlahnya pengusaha di suatu negara, semakin berkembang dan stabilnya perekonomian negara. Meningkatkan jumlah pengusaha juga berkorelasi positif dengan kenaikan lapangan kerja dan kenaikan di tingkat kesejahteraan sosial. Dengan demikian, jumlah pengusaha adalah cerminan ekonomi suatu negara maju. Jumlah pengusaha di Indonesia hanya sekitar 1,65 
Jurnal Ilmiah Ekonomi dan Bisnís

Vol. 15. No. 2, September 2018: 139-149

EISSN : $2442-9813$

ISSN : $1829-9822$

persen dari populasi jumlah ideal yang harus dicapai adalah 2 persen (Kementerian Koperasi dan Usaha Kecil dan Menengah Indonesia, 2015).

Saat ini, pendidikan tinggi

memegang peranan penting

menghasilkan peningkatan jumlah

lulusan di banyak negara dan kebijakan

pemerintah di berbagai negara berusaha

mengarahkan kewirausahaan sebagai

pilihan karier yang tepat, salah satu

alasan karena tingginya tingkat persaingan untuk mendapatkan pekerjaan di "perusahaan besar" di pasar tenaga kerja (Nabi \& Holden, 2008). Sebuah studi oleh (Indarti, Rostiani, \& Nastiti, 2010) menunjukkan bahwa latar belakang pendidikan menjadi kunci faktor yang mempengaruhi niat kewirausahaan di antara mahasiswa indonesia. Beberapa penelitian menunjukkan bahwa Kecenderungan kewiraswastaan dikaitkan dengan beberapa karakteristik pribadi yang bisa terpengaruh oleh sebuah program pendidikan formal (Gorman, G., Hanlon, D., \& King, 1997);(Bechard, J. P., \& Toulouse, 1998). Beberapa Penelitian telah memastikan bahwa perguruan tinggi itu berperan positif dalam pengembangan niat dan perilaku mahasiswa untuk berwirausaha (Hannon, 2005). Hal ini mendorong fungsi strategis untuk meningkatnya jumlah pengusaha dengan memasukkan nilai kewirausahaan dalam proses pembelajaran. Vesper 1990 dalam(Simanjuntak et al., 2016) mengemukakan bahwa pengajar di universitas bisa memfasilitasi proses kewirausahaan dengan menciptakan kesadaran di kalangan mahasiswa perguruan tinggi. Oleh karena itu mahasiswa merupakan salah satu kelompok generasi muda yang penting diperhatikan dalam kreatifitas dan kemampuannya dalam kewirausahaan.

Selain pendidikan formal, konsep diri juga merupakan faktor yang perlu dipertimbangkan dalam membentuk potensi kewirausahaan. Konsep diri meliputi citra diri dan sifat kepribadian yang telah ditinjau secara luas sebagai faktor yang berpengaruh terhadap potensi kewirausahaan. (Timmons, Jeffry, A., \& Spinelli, 1999) telah melakukan penelitian tentang ciri kepribadian, disebutkan bahwa ciri kepribadian sangat erat kaitannya untuk potensi kewirausahaan dan dapat membedakan pengusaha dari non-pengusaha. Sementara itu, pengaruh konsep diri terhadap kewirausahaanPotensi belum banyak diteliti.

Fakultas Ekonomi Universitas Lancang Kuning sebagai sebuah institusi yang fokus pada pembinaan kewirausahaan mahasiswa. Untuk menghadapi persaingan, khususnya pada Fakultas Ekonomi dan lebih fokus pada program studi manajemen, menerapkan program unggulannya adalah kewirausahaan (Suroto, 2016). Hal ini tertera pada Rencana Strategis (Renstra) Fakultas dan pelaksanaannya dengan memiliki sebuah inkubator kewirausahaan. Potensi kewirausahaan dari mahasiswa khususnya mahasiswa Fakultas Ekonomi Universitas Lancang Kuning sangat penting untuk diidentifikasi agar dapat mengetahui tingkat dari potensi yang dimiliki sehingga kedepannya akan memudahkan para dosen, motivator, ataupun mentor yang mengajar untuk menentukan proses pembelajaran yang tepat dalam meningkatkan kemampuan wirausaha pada mahasiswa. Selain itu nantinya dapat menjadi salah satu unsur pendukung dalam mencapai rencana fakultas ekonomi Universitas Lancang Kuning kedepan. Berdasarkan penjelasan diatas, peneliti tertarik untuk melakukan penelitian tentang tingkat peran pendidikan formal dan konsep diri, serta tingkat potensi kewirausahaan mahasiswa. Selain itu itu ingin menganalisa pengaruh pendidikan formal dan konsep diri terhadap potensi 
kewirausahaan mahasiswa, yang dalam penelitian ini terbatas pada mahasiswa program studi manajemen Fakultas Ekonomi Universitas Lancang Kuning.

\section{TINJAUAN PUSTAKA}

Kewirausahaan sebagai kreasi dari memulai usaha baru (Simanjuntak et al., 2016). Definisi ini menekankan bahwa seorang wirausaha adalah orang yang mampu melihat peluang dan menciptakan manfaat dari peluang tersebut (Bagus, Satrya, \& Suwandana, 2015). Proses kewirausahaan meliputi semua kegiatan dan tindakan untuk mengejar dan memanfaatkan peluang. Kewirausahaan adalah konsep dasar yang menghubungkan berbagai bidang ilmu yang berbeda, antara lain; ekonomi, sosiologi, dan sejarah. Kewirausahaan bukan hanya di bidang interdisiplin yang biasa dilihat atau ditemukan di institusi pendidikan, melainkan pokok-pokok yang menghubungkan kerangka konseptual utama dari berbagai disiplin ilmu dan dianggap sebagai kunci dari blok bangunan ilmu sosial yang terintegrasi (Casson, 2012). Wirausaha adalah menggeluti usaha tidak sekedar ala kadarnya, akan tetapi dengan keberanian, kegigihan sehingga usahanya tumbuh dan bersahabat dengan ketidakpastian serta menjalankan usaha yang riil, bukan spekulatif. Makna ini menegaskan bahwa keberhasilan dalam berwirausaha selalu dihadapkan pada kenyataan yang di masa depan belum tau dengan jelas apa sesungguhnya yang dihadapi, berbagai peluang dapat ditangkap dan hal inilah yang membutuhkan kemampuan melihat peluang ke depan (Suroto, 2016).

Sisi lain mengenai kewirausahaan adalah salah satu dari sejumlah masukan yang berkontribusi terhadap keseluruhan penampilan ekonomi suatu negara, bersama-sama dengan komponen modal dan sumberdaya manusia. Hal tersebut adalah dipandang sebagai faktor masukan (input) yang memperbaiki efisiensi perekonomian dan merupakan subtitusi terhadap faktor lainnya. Kewirausahaan diakui sebagai suatu aspek bisnis yang menempati posisi penting untuk meningkatkan vitalitas dan pertumbuhan ekonomi suatu negara. Mahasiswa dan lulusan perguruan tinggi, seringkali melihat bahwa pekerjaan di bidang kewirausahaan adalah sebagai suatu alternatif pilihan karir yang menarik. Kewirausahaan dipandang sebagai representasi

kebebasan, realisasi diri, dan lebih bergengsi daripada pekerjaan sebagai karyawan pada suatu perusahaan/organisasi (Luthje, C., and Franke, 2003). Jadi, kewirausahaan mencerminkan alternatif penanggulangan pengangguran dan/atau diskriminasi di pasar kerja, dan sebagai jalur pengentasan kemiskinan.

Potensi diri merupakan kemampuan, kekuatan, baik yang belum terwujud maupun yang telah terwujud, yang dimiliki seseorang, tetapi belum sepenuhnya terlihat atau dipergunakan secara maksimal (Bagus et al., 2015) Jadi kalau dihubungkan dengan kewirausahaan berarti kemampuan, kekuatan yang dimiliki seseorang dalam berusaha atau melakukan suatu usaha. Menurut (Bagus et al., 2015) secara umum potensi dapat diklasifikasikan sebagai berikut:

1) Kemampuan dasar, seperti tingkat intelegensi, kemampuan abstraksi, logika dan daya tangkap.

2) Etos kerja, seperti ketekunan, ketelitian, efisiensi kerja dan daya tahan terhadap tekanan.

3) Kepribadian, yaitu pola menyeluruh semua kemampuan, perbuatan, serta kebiasaan seseorang, baik jasmaniah, rohaniah, emosional maupun sosial yang ditata dalam cara khas di bawah aneka pengaruh luar 
Jurnal Ilmiah Ekonomi dan Bisnís

Vol. 15. No. 2, September 2018: 139-149

EISSN : $2442-9813$

ISSN : $1829-9822$

Potensi utama dalam membangun dan mengembangkan kewirausahaan yang berhasil bermula dari pendidikan dan pengalaman bisnis kecil-kecilan yang dimiliki oleh seseorang (Alma, 2009). Dorongan membentuk wirausaha juga datang dari temen pergaulan, lingkungan keluarga, masyarakat, sahabat dimana mereka dapat berdiskusi tentang ide dan masalah yang dihadapi serta cara mengatasinya. Menurut Zimmerer et al dalam (Bagus et al., 2015) mengatakan membuka dan menjalankan sebuah bisnis tidak memberi jaminan bahwa pengusaha akan menghasilkan cukup uang untuk hidup, tapi kesuksesan bisnis datang dari peluang untuk menggunakan potensi diri sepenuhnya.

Menumbuhkan jiwa wirausaha mahasiswa dimulai dari minat. Minat merupakan faktor utama yang tidak dimiliki oleh mahasiswa dalam bidang menghasilkan uang. Padahal dari segi manfaat dengan melakukan aktivitas dengan modal utamanya adalah berani, maka selain untuk kepentingan pribadi mahasiswa, juga untuk kepentingan negeri yang membutuhkan kompetensi pribadi-pribadi yang bisa berkontribusi di dalam menanggulangi kemiskinan. Sebagian, ada yang antusias dan bersemangat mengikutinya, dan ada juga yang semangatnya hanya di mulut saja namun tidak di aplikasikan. Di sisi lain, ada yang bersemangat namun dengan alasan tidak memiliki bakat, dan yang lebih parah ada yang tidak tahu sama sekali. Banyak manfaat yang bisa diambil, terutama bagi mahasiswa tingkat akhir untuk mendapat modal dasar mendirikan usaha.

Program kewirausahaan diharapkan dapat mengurangi pengangguran intelektual yang tergerak untuk berkompetisi, walaupun dari jumlah lulusannya hanya setengah yang mengaplikasikan proposal secara nyata. Alasan terbesar dari mahasiswa yang tidak ikut bersaing dalam menjalankan usaha adalah tidak berbakat.

Pendidikan formal adalah pendidikan untuk upaya baru dalam mentransfer pengetahuan dan pengembangan keterampilan yang relevan yang meningkatkan kemampuan diri dan efektifitas dari potensi berwirausaha (Gorman, G., Hanlon, D., \& King, 1997) ; (Simanjuntak et al., 2016) Jones \& English,(2004) berpendapat bahwa "lingkungan belajar yang berbeda diperlukan untuk mendukung studi tentang kewirausahaan dalam lingkungan universitas. Intinya, gaya mengajar itu berorientasi pada tindakan, mendorong pembelajaran pengalaman, pemecahan masalah, berbasis proyek belajar, kreativitas, dan mendukung evaluasi sejawat. (Kickul, J. and Fayole, 2007) juga menganjurkan model pendidikan kewirausahaan interdisipliner termasuk metode pengajaran "yang memungkinkan untuk belajar dalam kondisi ambiguitas dan ketidakpastian. Mereka merekomendasikan menciptakan lingkungan yang memungkinkan siswa untuk mengembangkan "pengalaman langsung dan pribadi" dan "rasa pribadi prestasi atau kegagalan untuk hasil yang diperoleh. Saat membahas apa metode terbaik memungkinkan dan mempertahankan pembelajaran kewirausahaan (Kickul, J. and Fayole, 2007) menargetkan "hasil belajar yang secara khusus berasal dari pemberlakuannya sebuah kegiatan, bukan dari lingkungan kelas tradisional". Hal ini juga menggambarkan nilai dan kebutuhan pengalaman di menciptakan pembelajaran bagi pengusaha. Mereka berpendapat, "Penelitian telah mengungkapkan bahwa strategis pengembangan dan perubahan dalam perusahaan kecil dan menengah terutama muncul dari kombinasi antara pengetahuan dan reaksi terhadap kejadian kritis. Dengan demikian, belajar dari pengalaman dianggap sangat penting bagi 
pengusaha dan pertumbuhan organisasi mereka .

Scott et al,(1998) dalam (Mandel \& Noyes, 2016) mendeskripsikan tiga peran kunci untuk pendidikan kewirausahaan: pendidikan tentang perusahaan, pendidikan melalui perusahaan dan pendidikan untuk perusahaan. Mereka menggambarkan yang kedua dari ini sebagai "cara di mana proses pendidikan itu sendiri dapat ditingkatkan dengan menggunakan gaya pedagogik yang bekerja dan memanfaatkan "giat" situasi, termasuk pendekatan berbasis proyek yang berpusat pada siswa dan dunia nyata.

$$
\text { (Brazeal, } 1994 \text { dalam }
$$

(Simanjuntak et al., 2016) mengungkapkan bahwa kepribadian adalah faktor prediktif potensi kewirausahaan. Beberapa temuan penelitian dari berbagai negara juga menunjukkan bahwa ciri kepribadian mempengaruhi kecenderungan penciptaan kewirausahaan (Utsch dan Rauch, 2000; Mueller dan Thomas, 2001; (Hwee Nga \& Shamuganathan, 2010). Karakteristik yang dapat diprediksi perilaku individu yang menjelaskan perbedaan dalam tindakan individu dalam situasi yang sama (Llewellyn dan Wilson, 2003; (Hwee Nga \& Shamuganathan, 2010). Sifat kepribadian mungkin dipengaruhi oleh pribadi yang unik, diam, subjektif pengetahuan, nilai / keyakinan, persepsi dan pengalaman individu yang tidak mudah direplikasi. Sifat kepribadian setiap individu dapat berfungsi sebagai katalisator yang mempengaruhi persepsi risiko pengusaha dalam pengambilan keoutusan. Kepribadian proaktif telah ditemukan menjadi prediktor signifikan terutama niat memulai kewirausahaan.

Dalam kepribadian wirausaha ditemukan memiliki nilai toleransi yang lebih tinggi pada ambiguitas, lokus kontrol internal, kepribadian proaktif, self-efficacy dan kebutuhan untuk berprestasi dibandingkan dengan nonpengusaha dalam menjelaskan kesuksesan bisnis (Ong dan Ismail, 2008; Rauch dan Frese, 2007). Sebagian besar penelitian melibatkan hubungan antara ciri kepribadian tentang kewiraswastaan dan pengaturan organisasi menghasilkan temuan yang tidak meyakinkan

Studi-studi empiris tentang potensi kewirausahaan dan hubungan karakteritik individu dengan perilaku serta keberhasilan kewirausahaan, sudah banyak dilakukan. Akan tetapi, sebagian studi memfokuskan kajiannya pada tingkat individu, karena menurut Thang et al. (2009) dan Muller dan Goic (2002), potensi kewirausahaan dipresentasikan oleh segmen penduduk yang tidak hanya mempersepsikan bahwa peluang ada di lingkungannya, namun juga memiliki karakteristik personal untuk mendirikan usaha baru. Teori yang digunakan sebagai pedoman untuk mengkaji hubungan antara karakteristik personal dan potensi kewirausahaan adalah teori atribusi. Pendekatan atribusi digunakan untuk menganalisis, mengapa beberapa orang menjadi berpotensi sebagai wirausaha (Raab et al., 2002).

Namun konsep diri belum banyak dipelajari serta ciri kepribadian. Konsep diri dari penelitian ini dipandang sebagai ' persepsi tentang dirinya sendiri tentang kemampuan atau karakter memiliki dasar penting untuk menjadi seorang entrepreneur, seperti kemampuan menjadi pelopor, selfreliance, persaingan, keinginan kuat, kemampuan untuk merencanakan, beradaptasi, menerima masukan dan membangun tim. (Jones \& English, 2004), berpendapat bahwa "lingkungan belajar yang berbeda diperlukan untuk mendukung studi tentang kewirausahaan dalam lingkungan universitas. Intinya, gaya mengajar itu berorientasi pada tindakan, mendorong pembelajaran pengalaman, pemecahan masalah, berbasis proyek belajar, kreativitas, dan mendukung evaluasi 
Jurnal Ilmiah Ekonomi dan Bisnis

Vol. 15. No. 2, September 2018: 139-149

EISSN : $2442-9813$

ISSN : $1829-9822$

sejawat. (Kickul, J. and Fayole, 2007) juga menganjurkan model pendidikan kewirausahaan interdisipliner termasuk metode pengajaran "yang memungkinkan untuk belajar dalam kondisi ambiguitas dan ketidakpastian.

\section{METODE PENELITIAN}

Metode pengumpulan data yang digunakan dalam penelitian ini adalah metode survei yang menggunakan daftar pertanyaan (kuesioner). Lokasi penyebaran kuesioner direncanakan di Fakultas Ekonomi Universitas Lancang Kuning. Metode pengambilan sampel yang digunakan adalah quota sampling (Sugiyono, 2008). Quota sampling adalah teknik untuk menentukan sampel dari populasi yang mempunyai ciri-ciri tertentu sampai jumlah (kuota) yang diinginkan.

Dalam penelitian ini jumlah sampel yaitu mahasiswa program studi Manajemen Fakultas Ekonomi Universitas Lancang Kuning sebesar 100 orang. Metode analisis data dengan melakukan tabulasi dari masing-masing indikator variabel untuk mengidentifikasi rata-rata potensi kewirausahaan mahasiswa, peran pendidikan formal dan konsep diri. Uji pengaruh dengan regresi berganda variabel independen (variabel X) yang diperhitungkan pengaruhnya terhadap variabel dependen (variabel $\mathrm{Y}$ ), jumlahnya lebih dari satu.

\section{HASIL DAN PEMBAHASAN}

Berdasarkan hasil pengumpulan data kuesioner didapatkan profil responden usia responden mulai 19 tahun sampai dengan 24 tahun. Jenis kelamin dominan adalah perempuan. Dalam profil rensponden juga mencantumkan keadaan mahasiswa antara hanya kuliah atau kuliah sambil bekerja. Sebanyak $72 \%$ responden dalam keaadaan kuliah sambil bekerja, seperti yang terdapat pada tabel dibawah ini:
Tabel 1. Profil Responden

\begin{tabular}{|c|c|c|c|}
\hline Profil & Kategori & Jumlah & ersentase \\
\hline Usia & $\begin{array}{l}19 \\
20 \\
21 \\
22 \\
23 \\
24\end{array}$ & $\begin{array}{c}5 \\
24 \\
38 \\
20 \\
10 \\
3\end{array}$ & $\begin{array}{c}5 \% \\
24 \% \\
38 \% \\
20 \% \\
10 \% \\
3 \%\end{array}$ \\
\hline \multicolumn{2}{|c|}{ Jumlah } & 100 & $100 \%$ \\
\hline \begin{tabular}{|l} 
Jenis \\
Kelamin
\end{tabular} & $\begin{array}{c}\text { Laki-laki } \\
\text { Perempuan }\end{array}$ & $\begin{array}{l}23 \\
77\end{array}$ & $\begin{array}{l}23 \% \\
77 \%\end{array}$ \\
\hline \multicolumn{2}{|c|}{ Jumlah } & 100 & $100 \%$ \\
\hline Semster & $\begin{array}{c}4 \\
6 \\
8 \\
10 \text { keatas }\end{array}$ & $\begin{array}{c}32 \\
38 \\
39 \\
1 \\
1\end{array}$ & $\begin{array}{c}32 \% \\
38 \% \\
39 \% \\
1 \% \\
1 \%\end{array}$ \\
\hline \multicolumn{2}{|c|}{ Jumlah } & 100 & $100 \%$ \\
\hline Keadaan & $\begin{array}{c}\text { Kuliah } \\
\text { Kuliah sambil }\end{array}$ & $\begin{array}{l}72 \\
28\end{array}$ & $\begin{array}{l}72 \% \\
28 \%\end{array}$ \\
\hline & & & 1 \\
\hline
\end{tabular}

Berdasarkan tabel 1 terlihat bahwa Sedangkan sisanya dalam keadaaan kuliah saja. Peran pendidikan formal diukur melakui 4 indikator. Adapun hasil pengumpulan data dan pengukuran tingkat respon pada setiap indikator pada peran pendidikan formal sebagaimana ditampilkan pada tabel dibawah ini :

Tabel 2. Pendidikan Formal

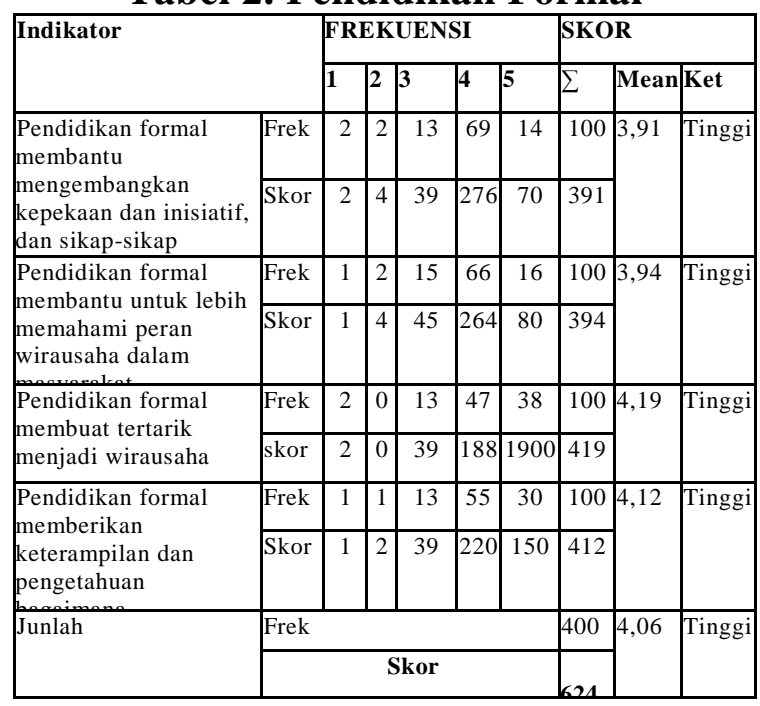

Sumber: Data Olahan (Hasil Kuesioner)

Tabel 2 memperlihatkan bahwa ke empat indikator pada variabel peran 
Tabel 3. Konsep Diri

pendidikan formal memiliki skor pada kategori baik, artinya mayoritas mahasiswa program studi manajemen Fakultas Ekonomi Universitas Lancang Kuning merasakan bahwa pendidikan formal yang mereka dapatkan di kampus membantu dalam memberikan peningkatan keinginan dalam berwirausaha, memahami peran-peran wirausaha dalam masyarakat, serta memberikan pengetahuan dan keterampilan bagaimana menjalankan bisnis. Artinya kegiataan-kegiatan untuk mahasiswa yang dirancang oleh pihak fakultas ekonomi dan Universitas Lancang kuning dapat dikatakan berhasil meningkatkan keinginan mahasiswa dalam berwirausaha serta mendapatkan pengetahuan dalam keterampilan menjalankan bisnis. Hal ini sesuai dengan kurikulum program studi manajemen, mahasiswa mendapatkan mata kuliah pokok kewirausahaan 1 dan kewirausahaan 2. Berbagai seminar sudah diadakan dengan mengundang narasumber dari internal maupun pihak luar kampus, pelatihan, magang yang berkaitan dengan kewirausahaan untuk mahasiswa sudah pernah diadakan oleh pihak fakultas maupun dari Universitas Lancang Kuning.

Konsep Diri diukur melakui 9 indikator. Adapun hasil pengumpulan data dan pengukuran tingkat respon pada setiap indikator pada konsep diri mahasiswa bahwa 9 indikator yang mendukung konsep diri pada mahasiswa program studi manajemen memiliki skor pada kategori baik. Skor teringgi pada indikator dapat menerima nasehat dengan rata-rata 4,25. Sebagaimana ditampilkan pada tabel di bawah ini :

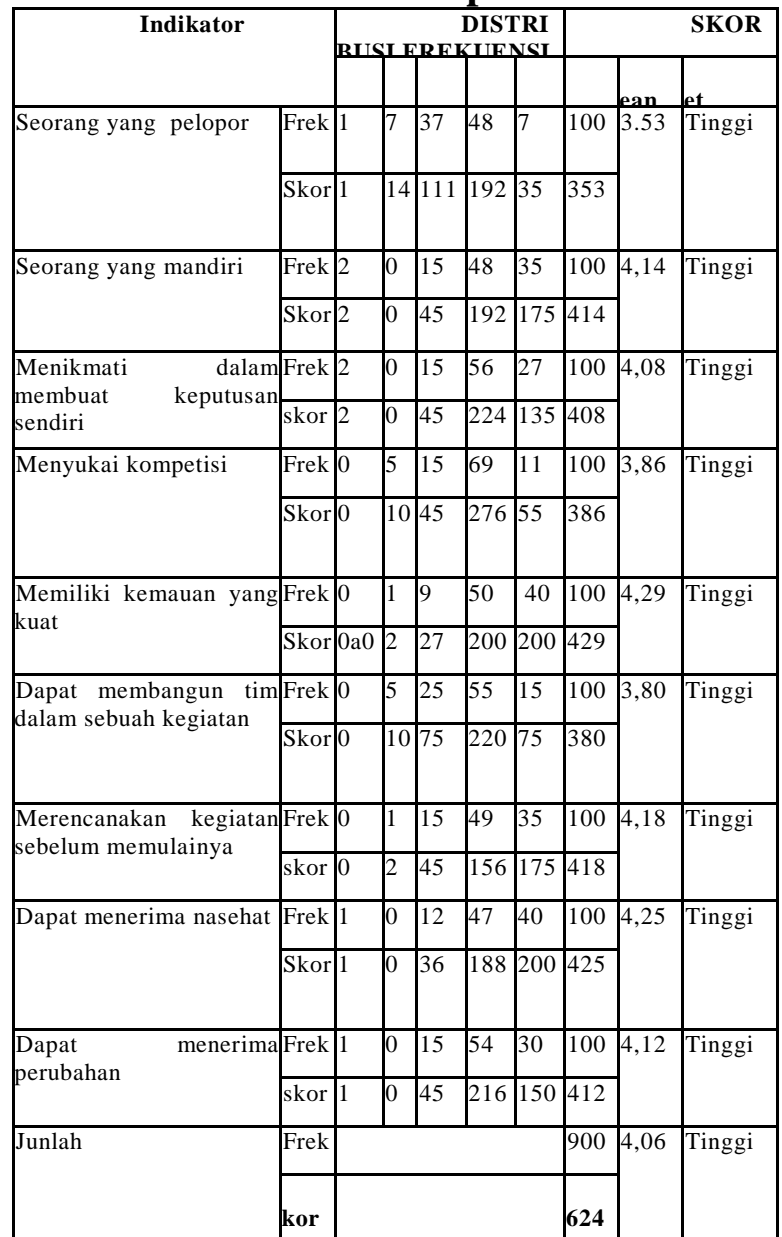

Sumber : Data Olahan (Hasil Kuesioner)

Berdasarkan tabel diatas memperlihatkanSedangkan skor paling rendah pada indikator seorang yang pelopor dengan rata-rata 3,53. Skor menunjukkan sebagian besar mahasiswa merasakan memiliki konsep diri yang baik. Konsep diri mahasiswa tentu dipengaruhi oleh berbagai hal diantaranya pengetahuan dan pengalaman yang mereka dapatkan. Dalam penelitian ini, yang mengisi kuesioner penelitian adalah mahasiswa semester empat keatas, dengan pertimbangan mereka sudah lebih lama berinteraksi di kampus Universitas Lancang Kuning dan sudah mengikuti matakuliah kewirausahaan 1 dan 2 .

Adapun hasil pengumpulan data dan pengukuran tingkat respon pada setiap indikator pada potensi 
Jurnal Ilmiah Ekonomi dan Bísnis

Vol. 15. No. 2, September 2018: 139-149

EISSN : $2442-9813$

ISSN : $1829-9822$

kewirausahaan mahasiswa sebagaimana ditampilkan pada tabel dibawah ini :

Tabel 4. Potensi Kewirausahaan

\begin{tabular}{|c|c|c|c|c|c|c|c|c|c|}
\hline \multirow[t]{2}{*}{ Indikator } & & \multicolumn{5}{|c|}{ DISTRIBUSI } & \multicolumn{3}{|c|}{ SKOR } \\
\hline & & & \multicolumn{2}{|c|}{\begin{tabular}{l|l} 
USI \\
4 & 5
\end{tabular}} & I & Mea & Ket \\
\hline \multirow{3}{*}{$\begin{array}{l}\text { Suka bekerja sama } \\
\text { dengan seseorang yang } \\
\text { ahli untuk mencapai } \\
\text { prestasi }\end{array}$} & Frek & 3 & 0 & 5 & 36 & 56 & 100 & \multirow[t]{3}{*}{4.42} & \multirow[t]{3}{*}{ Tingg } \\
\hline & Skor & 3 & 0 & 15 & & 280 & 442 & & \\
\hline & & & & & 144 & & & & \\
\hline \multirow{2}{*}{$\begin{array}{l}\text { Memiliki jadwal yang } \\
\text { pasti dalam setiap } \\
\text { aktifitas }\end{array}$} & Frek & 2 & 2 & 28 & 46 & 22 & 100 & \multirow[t]{2}{*}{3.84} & \multirow[t]{2}{*}{ Tingg } \\
\hline & Skor & 2 & 4 & 84 & 184 & 110 & 384 & & \\
\hline \multirow{2}{*}{$\begin{array}{l}\text { Mengikuti jadwal yang } \\
\text { sudah dibuat }\end{array}$} & Frek & 1 & 2 & 26 & 52 & 19 & 100 & \multirow[t]{2}{*}{3.86} & \multirow[t]{2}{*}{ Tingg } \\
\hline & skor & 1 & 4 & 78 & 208 & 95 & 386 & & \\
\hline \multirow{2}{*}{$\begin{array}{l}\text { Mampu mengidentifikasi } \\
\text { secara cepat dan } \\
\text { mengatasi masalah yang } \\
\text { menghalangi untuk } \\
\text { membuat keputusan }\end{array}$} & Frek & 1 & 1 & 23 & 66 & 9 & 100 & \multirow[t]{2}{*}{3.81} & \multirow[t]{2}{*}{ Tingg } \\
\hline & Skor & 1 & 2 & 69 & 264 & 45 & 381 & & \\
\hline \multirow{2}{*}{$\begin{array}{l}\text { Mampu membuat orang } \\
\text { lain mengikuti jadwal } \\
\text { saya }\end{array}$} & Frek & 1 & 7 & 45 & 39 & 8 & 100 & \multirow[t]{2}{*}{3.46} & \multirow[t]{2}{*}{ Tingg } \\
\hline & skor & 1 & 14 & 135 & 156 & 40 & 346 & & \\
\hline \multirow{2}{*}{$\begin{array}{l}\text { Mampu mengatasi } \\
\text { permasalahan yang } \\
\text { kompleks dengan baik }\end{array}$} & Frek & 1 & 2 & 26 & 63 & 8 & 100 & \multirow[t]{2}{*}{3.75} & Tingg \\
\hline & Skor & 1 & 4 & 78 & 252 & 40 & 375 & & \\
\hline Dapat memutuskan & Frek & 2 & 5 & 28 & 56 & 9 & 100 & 3.65 & Tingg \\
\hline & skor & 2 & 10 & 84 & 224 & 45 & 365 & & \\
\hline Mampu bekerja dalam & Frek & 3 & 3 & 23 & 40 & 21 & 100 & 3.63 & Tingg \\
\hline & Skor & 3 & 26 & 69 & 160 & 105 & 5363 & & \\
\hline Memiliki stamina fisik & Frek & 3 & 5 & 27 & 49 & 16 & 100 & 3.70 & Tingg \\
\hline $\begin{array}{l}\text { mengerjakan proyek } \\
\text { jangka panjang }\end{array}$ & skor & 3 & 10 & 81 & 196 & 80 & 370 & & \\
\hline Memiliki emosi yang & Frek & 0 & 4 & 20 & 62 & 14 & 100 & 3.86 & Tingg \\
\hline $\begin{array}{l}\text { ketegangan atau } \\
\text { kegembiraan }\end{array}$ & Skor & 0 & 8 & 60 & 248 & 70 & 386 & & \\
\hline Rela berkorban untuk & Frek & 0 & 4 & 11 & 51 & 34 & 100 & 4.15 & Tingg \\
\hline diinginkan & skor & 0 & 8 & 33 & 204 & 170 & 415 & & \\
\hline Mampu mengidentifikasi & Frek & 0 & 0 & 27 & 50 & 23 & 100 & 3,96 & Tingg \\
\hline dibutuhkan untuk sukses & Skor & 0 & 0 & 81 & 200 & 115 & 396 & & \\
\hline Memiliki kete & Frek & 0 & 2 & 12 & 52 & 34 & 100 & 4,18 & Ting \\
\hline & skor & 0 & 4 & 36 & 208 & 170 & 418 & & \\
\hline Mengisi & Frek & 0 & 4 & 23 & 54 & 19 & 100 & 3,88 & Tingg \\
\hline & \begin{tabular}{|l|} 
Skor \\
\end{tabular} & 0 & 8 & 69 & 216 & 95 & 388 & & \\
\hline Tidak takut akan resiko, & Frek & 0 & 2 & 22 & 55 & 21 & 100 & 3,95 & Tingg \\
\hline $\begin{array}{l}\text { mengurangi resiko jika } \\
\text { memungkinkan }\end{array}$ & skor & 0 & 4 & 66 & 220 & 105 & 5395 & & \\
\hline Mampu hidup dalam & Frek & 4 & 6 & 23 & 53 & 14 & 100 & 3,67 & Tingg \\
\hline & Skor & 4 & 12 & 79 & & 70 & 367 & & \\
\hline Memiliki 1 & Frek & 0 & 2 & 25 & 57 & 16 & 100 & 3,87 & Tingg \\
\hline & Skor & 0 & 4 & 75 & 228 & 80 & 387 & & \\
\hline fokus pada tujuan & Frek & 0 & 1 & 6 & 52 & 41 & 100 & 4,33 & Tingg \\
\hline & or & 0 & 2 & 18 & 208 & 20 & 433 & & \\
\hline
\end{tabular}

\begin{tabular}{|c|c|c|c|c|c|c|c|c|c|}
\hline \multirow[t]{2}{*}{ Indikator } & & \multicolumn{5}{|c|}{ DISTRIBUSI } & \multicolumn{3}{|c|}{ SKOR } \\
\hline & & 1 & 2 & 3 & 4 & 5 & $\sum$ & Mea & Ket \\
\hline \multirow{2}{*}{$\begin{array}{l}\text { Menyakini tahu tujuan } \\
\text { yang ingin dicapai }\end{array}$} & Frek & 1 & 0 & 8 & 51 & 40 & 100 & \multirow[t]{2}{*}{4,29} & \multirow[t]{2}{*}{ Tingg } \\
\hline & Skor & 1 & 0 & 24 & 204 & 200 & 429 & & \\
\hline \multirow{2}{*}{$\begin{array}{l}\text { Mampu berkomunikasi } \\
\text { dengan orang lain }\end{array}$} & Frek & 1 & 0 & 13 & 51 & 35 & 100 & \multirow[t]{2}{*}{4,19} & \multirow[t]{2}{*}{ Tingg } \\
\hline & skor & 1 & 0 & 39 & 204 & 175 & 419 & & \\
\hline \multirow{2}{*}{$\begin{array}{l}\text { Mampu mengerjakan } \\
\text { pekerjaan lebih dari satu } \\
\text { dalam target waktu yang } \\
\text { sama }\end{array}$} & Frek & 0 & 1 & 32 & 42 & 25 & 100 & \multirow[t]{2}{*}{3,91} & \multirow[t]{2}{*}{ Tinggi } \\
\hline & Skor & 0 & 2 & 96 & 168 & 125 & 391 & & \\
\hline \multirow{2}{*}{$\begin{array}{l}\text { Memisahkan hal-hal yang } \\
\text { penting dan baik untuk } \\
\text { dilaksanakan }\end{array}$} & Frek & 2 & 1 & 9 & 63 & 25 & 100 & \multirow[t]{2}{*}{4,08} & \multirow[t]{2}{*}{ Tingg } \\
\hline & skor & 2 & 2 & 27 & 252 & 125 & 408 & & \\
\hline \multirow{2}{*}{$\begin{array}{l}\text { Tidak membiarkan } \\
\text { hubungan emosional } \\
\text { mengganggu bisnis saya }\end{array}$} & Frek & 0 & 2 & 10 & 51 & 37 & 100 & \multirow[t]{2}{*}{4,23} & \multirow[t]{2}{*}{ Tingg } \\
\hline & Skor & 0 & 4 & 30 & 204 & 185 & 423 & & \\
\hline \multirow{2}{*}{$\begin{array}{l}\text { Tidak akan membiarkan } \\
\text { urusan pribadi } \\
\text { menginterfensi bisnis }\end{array}$} & Frek & 0 & 2 & 7 & 48 & 43 & 100 & \multirow[t]{2}{*}{4,32} & \multirow[t]{2}{*}{ Tingg } \\
\hline & skor & 0 & 4 & 21 & 192 & 215 & 432 & & \\
\hline \multirow[t]{2}{*}{ Jumlah } & Frek & & & & & & 240 & \multirow[t]{2}{*}{4,06} & \multirow[t]{2}{*}{ Tinggi } \\
\hline & & & & & & & 624 & & \\
\hline
\end{tabular}

Sumber : Data Olahan (Hasil Kuesioner)

Berdasarkan tabel diatas memperlihatkan bahwa pada indikator yang mendukung potensi kewirausahaan pada mahasiswa program studi manajemen memiliki skor pada kategori baik. Skor tertinggi pada indikator "suka bekerja sama dengan seseorang yang ahli untuk mencapai prestasi" dengan rata-rata 4,42. Sedangkan skor paling rendah pada indikator "mampu membuat orang lain mengikuti jadwal saya" dengan rata-rata 3,46. Artinya mahasiswa memiliki sikapsikap yang berpotensi menjadikan mereka seorang wirausaha nantinya. Hasil ini sejalan dengan pendapat Alma (2009), potensi utama dalam membangun dan mengembangkan kewirausahaan yang berhasil bermula dari pendidikan dan pengalaman bisnis kecil-kecilan yang dimiliki oleh seseorang. Dorongan membentuk wirausaha juga datang dari temen pergaulan, lingkungan keluarga, masyarakat, sahabat dimana mereka dapat berdiskusi tentang ide dan masalah yang dihadapi serta cara mengatasinya

Berdasarkan hasil pengolahan data dengan menggunakan SPSS, maka persamaan regresi berganda yang dihasilkan adalah sebagai berikut : 
$Y=19.145+0.263 X_{1}+0.580 X_{2}+e$

Keterangan :

$$
\begin{aligned}
& Y=\text { Potensi Kewirausahaan } \\
& X_{1}=\text { Pendidikan Formal } \\
& X_{2}=\text { Konsep Diri }
\end{aligned}
$$

Dari hasil penelitian juga ditemukan bahwa pendidikan formal dan konsep diri memiliki pengaruh yang positif dan signifikan terhadap potensi kewirausahaan mahasiswa, artinya semakin baik pendidikan formal dan konsep diri pada mahasiswa, maka potensi kewirausahaan dalam diri mahasiswa akan semakin meningkat. Hasil penelitian ini sejalan dengan penelitian yang dilakukan (Simanjuntak, Awwaliyah, \& Artanto, 2016) dimana pendidikan formal dan konsep diri berpengaruh positif dan signifikan terhadap potensi kewirausahaan mahasiswa di Universitas Pertanian bogor. Beberapa temuan penelitian lain dari berbagai negara juga menunjukkan bahwa ciri kepribadian atau konsep diri mempengaruhi kecenderungan penciptaan kewirausahaan (Utsch dan Rauch, 2000; Mueller dan Thomas, 2001; (Hwee Nga \& Shamuganathan, 2010). Juga menurut Hadiyati (2017) bahwa jiwa kewirausahaan mahasiswa dipengaruhi oleh latar belakang pendidikan.

\section{KESIMPULAN DAN SARAN}

Hasil deskriptif data menunjukkan bahwa pendidikan formal, konsep diri, dan potensi kewirausahaan mahasiswa program studi manajemen fakultas ekonomi dalam kriteria baik. Pendidikan formal dan konsep diri secara positif dan signifikan mempengaruhi potensi kewirausahaan pada mahasiswa. Artinya peningkatan dalam kualitas pendidikan formal dan konsep diri akan meningkatkan potensi kewirausahaan pada mahasiswa.
Bagi pihak Fakultas Ekonomi Lancang Kuning harus terus meningkatkan kualitas pembelajaran mahasiswa, menambah fasilitas untuk seminar dan pelatihan dalam meningkatkan minat mahasiswa berwirausaha. Pihak kampus juga dapat memperkuat diri siswa-konsep dengan menanamkan nilai-nilai kewirausahaan dan pelatihan untuk membentuk konsep diri yang baik

Bagi peneliti selanjutnya diharapkan dapat menggunakan jumlah responden yang lebih banyak dari penelitian yang sekarang dan membedakan hasil deskriptif antara responden laki-laki dan perempuan

\section{DAFTAR PUSTAKA}

Alma, B. (2009). Kewirausahaan. Bandung: Alfabeta.

Bagus, I. G., Satrya, H., \& Suwandana, I. G. M. (2015). UNIVERSITAS UDAYANA Fakultas Ekonomi Universitas Udayana ( Unud ), Bali , Indonesia kerja , karena kemampuan pemerintah untuk itu sangat terbatas . Wirausaha merupakan perekonomian suatu bangsa . Perkembangan teori dan definisi wirausaha berawal dari ekon, 4(12), 4559-4594.

Bechard, J. P., \& Toulouse, J. M. (1998). Validation of a didactic model for the analysis of training objectives in entrepreneurship, 13(4), 317332.

Casson, M. (n.d.). Entrepreneurship: Teori, Jejaringdan Sejarah. Depok: Rajawali Press.

Gorman, G., Hanlon, D., \& King, W. (1997). Some research perspectives on entrepreneurship education, enterprise education and education for small business management: a ten-year literature 
Jurnal Ilmiah Ekonomi dan Bisnis

Vol. 15. No. 2, September 2018: 139-149

EISSN : $2442-9813$

ISSN : 1829-9822

review. International Small Business Journal, 15(3), 15-79.

Hannon, P. D. (2005). The journey from student to entrepreneur. A review of the existing research into graduate entrepreneurship. International Entrepreneurship Conference.

Hwee Nga, J. K., \& Shamuganathan, G. (2010). The influence of personality traits and demographic factors on social entrepreneurship start up intentions. Journal of Business Ethics, 95(2), 259-282. https://doi.org/10.1007/s10551009-0358-8

Indarti, N., Rostiani, R., \& Nastiti, T. (2010). Underlying Factors of Entrepreneurial Intenttions among Asian Students. The South East Asian Journal of Management.

Jones, C., \& English, J. (2004). A contemporary approach to entrepreneurship education. Education + Training, 46(8/9), 416-423.

https://doi.org/10.1108/00400910 410569533

Kementerian Koperasi dan Usaha Kecil dan Menengah Indonesia. (2015). wirausaha progresif di negara berkembang. Retrieved from http://www.depkop.go.id/

Kickul, J. and Fayole, A. (2007). Cornerstones of Change: Revisiting and Challenging New Perspectives on Research in Entrepreneurship Education. Handbook of Research in Entrepreneurship Education, 1, $1-16$.
Luthje, C., and Franke, N. (2003). The "making" of an entrepreneur: testing a model of entrepreneurial intent among engineering students at MIT. Research \& Development Management, 33(2), 135-147.

Mandel, R., \& Noyes, E. (2016). Survey of experiential entrepreneurship education offerings among top undergraduate entrepreneurship programs. Education + Training, $58(2)$, 164-178. https://doi.org/10.1108/ET-062014-0067

Nabi, G., \& Holden, R. (2008). Graduate entrepreneurship: intentions, education and training. Education + Training, 50(7), 545-551. https://doi.org/10.1108/004009108 10909018

Nyadu-Addo, R., \& Mensah, M. S. B. (2017). Entrepreneurship education in Ghana - the case of the KNUST entrepreneurship clinic. Journal of Small Business and Enterprise Development, JSBED-02-2017-0062. https://doi.org/10.1108/JSBED-022017-0062

Simanjuntak, M., Awwaliyah, I., \& Artanto, R. J. (2016). The Entrepreneurial Potential among Undergraduate Students Potensi Wirausaha antara Mahasiswa Sarjana, XVII(2), 75-84.

Sugiyono. (2008). Metode Penelitian Bisnis. Bandung: Alfabets.

Suroto, B. (2016). Identifikasi Jiwa Kewirausahaan Mahasiswa ( Studi Kasus Pelaksanaan Program Unggulan Kewirausahaan ). Jurnal Benefita, 1(3), 154-162. 
Timmons, Jeffry, A., \& Spinelli, S.

(1999). New venture creation:

Entrepreneurship for the 21st century.".

Unilak, H., Unilak, B. S., Unilak, F., \& Unilak, N. (2017). Jiwa kewirausahaan mahasiswa tempatan (studi mahasiswa bidang ekonomi di kota pekanbaru). Journal of Techno Social, 9(1). 